\title{
Potential Inundation Hazards in the Taipei Basin Induced by Reactivation of the Shanchiao Fault in Northern Taiwan
}

\author{
Jihn-Sung Lai ${ }^{1,2}$, Chun-Ying Chiu ${ }^{3}$, Hsiang-Kuan Chang ${ }^{1,2}$, Jyr-Ching $\mathrm{Hu}^{3, *}$, and Yih-Chi Tan $^{1,2}$ \\ ${ }^{1}$ Hydrotech Research Institute, National Taiwan University, Taipei, Taiwan, ROC \\ ${ }^{2}$ Department of Bioenvironmental Systems Engineering, National Taiwan University, Taipei, Taiwan, ROC \\ ${ }^{3}$ Department of Geosciences, National Taiwan University, Taipei, Taiwan, ROC
}

Received 16 June 2008, accepted 22 February 2010

\begin{abstract}
The Shanchiao fault, located to the west of the Taipei Basin in northern Taiwan, is a highly active normal fault that has a left-slip component and fault length of over $40 \mathrm{~km}$. We suggest that the Shanchiao fault still has the ability to induce coseismic subsidence in the Taipei Basin under present extensional regime of northern Taiwan. In order to characterize the coseismic ground deformation and assess the potential inundation hazards in Taipei Basin, we estimate surface displacements using elastic dislocation models. The largest slip is assumed to be located underneath the Kuandu area due to the observation of deepest Tertiary basement in this area. Based on the topography changes due to coseismic deformation in a potential magnitude 7 event induced by reactivation of the Shanchiao fault, a 2D inundation model was adopted to simulate several inundation scenarios, including potential flood inundation below high tide condition and under various return-period design rainfall events. The predicted inundation maps based on various return-period flood events can provide information to assess potential earthquake-induced inundation hazards.
\end{abstract}

Key words: Earthquake-induced inundation hazards, Shanchiao fault, Taipei Basin

Citation: Lai, J. S., C. Y. Chiu, H. K. Chang, J. C. Hu, and Y. C. Tan, 2010: Potential inundation hazards in the Taipei Basin induced by reactivation of the Shanchiao fault in northern Taiwan. Terr. Atmos. Ocean. Sci., 21, 529-542, doi: 10.3319/TAO.2010.02.22.01(TH)

\section{INTRODUCTION}

Located west of the Taipei Basin, the Shanchiao fault is a highly active normal fault that has left-slip component and fault length is over $40 \mathrm{~km}$ (Fig. 1). Therefore, an assessment of the seismic hazards is a critical need for the highly urbanized Taipei metropolitan area (e.g., Wang et al. 2006; Wang 2008). In addition, according to historical documents, an earthquake large enough to destroy an aboriginal house and produce an earthquake-induced lake "Kanshi Taipei Lake" might have occurred in this area during April 1694 (Hsu 1983). Consequently, the potential inundation induced by a large earthquake along the Shanchaio fault is an important issue for natural hazard mitigation in this area. During the past few decades, several deep boreholes have been investigated to provide geological information about the geometry of basement rocks, stratigraphic sequences, and coseismic slip of paleoearthquakes (Huang et al. 2007).

\footnotetext{
* Corresponding author

E-mail:jchu@ntu.edu.tw
}

Surface overland flow processes are primarily determined by topography, land cover and soil characteristics. They can generally be described by a two-dimensional (2D) diffusive overland-flow model based on non-inertia surface flow dynamics in rural areas (Wasantha Lal 1998). For 2D inundation models, the mathematical equations governing flows over watershed surface are dynamic wave equations. It is difficult to use dynamic wave equations for the analysis of a distributed surface with adverse slopes and irregular geometry in a floodplain. If inertial terms are relatively apparent in the governing phenomena, such as rapidly rising stage flood or dam-break flows, then the dynamic wave equations must be completely considered. On the other hand, a simplified form of the dynamic wave equations, the non-inertia wave (diffusion wave) model, neglecting the inertial terms but considering the backwater effect, is physically applicable to simulate regional overland flow in floodplains. A diffusive-wave model was first proposed by Cunge et al. (1976), and similar approaches have been developed and 
applied by many researchers (Vongvisessomjao et al. 1985; Bates et al. 2003). Hsu et al. (1990) and Wasantha Lal (1998) compared the performance of various numerical schemes on developing 2D diffusive-wave models, including an explicit scheme, simply explicit scheme (SES), alternating direction implicit scheme (ADI) and an alternating direction explicit scheme (ADE). The diffusive-wave model can accurately predict flood inundation processes according to various land uses and detailed topographic data (Hsu et al. 2002; Yu and Lane 2006). In this study, a 2D diffusive-wave model, namely the 2D inundation model, with ADE scheme was adopted to simulate flood inundation.

The 2D inundation model adopting ADE scheme is verified by using the measured data in the Typhoon Nari event. Based on the topography changes resulting from coseismic deformation in a potential magnitude 7 event, the $2 \mathrm{D}$ inundation model is employed to simulate several scenarios of inundation conditions, including potential flood inundation under high tide and flood simulations in various return-period design rainfall events. The simulated inundation depth and areas based on various return-period events can provide information to disaster emergency responses and flood mitigation measures for the infrastructure planning.

\section{GEOLOGICAL AND HYDROLOGICAL BACK- GROUND}

\subsection{Geological Setting}

Taiwan is located on the convergent boundary between the Philippine Sea plate and Eurasian plate (Fig. 1a). The convergence rate is about $8 \mathrm{~cm} \mathrm{yr}^{-1}$ (Hu et al. 2001; Lin et al. 2010). The Taiwan mountain belt has resulted from the collision between the Luzon arc and the Eurasian continent about 5 Ma ago (Ho 1986; Teng 1990, 1996) and produced the fold-and-thrust belt in western Taiwan. The fold-andthrust belt of Taiwan advanced northwestward, while the

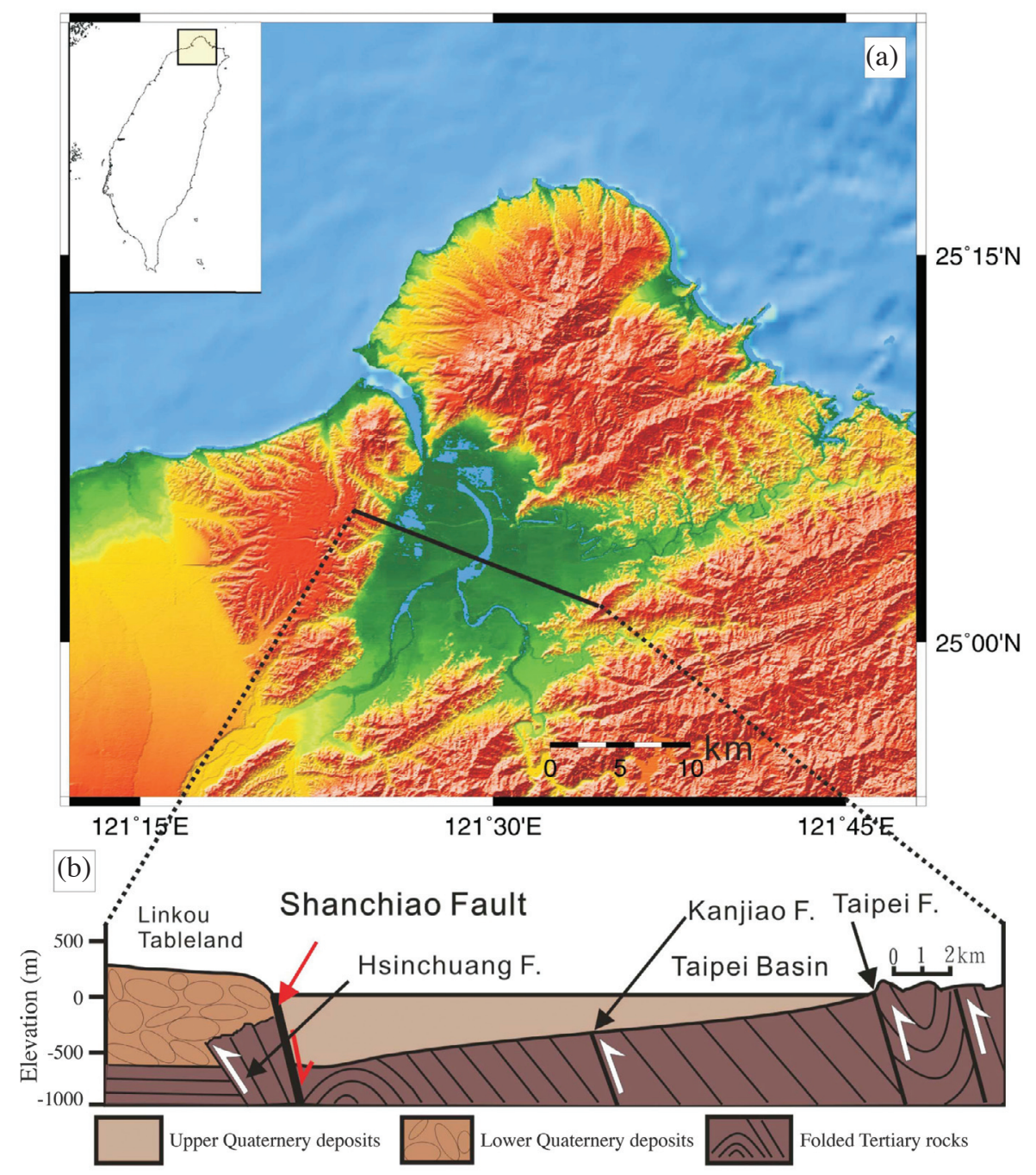

Fig. 1. (a) Topographic feature of the Taipei Basin. (b) Simplified geological cross section of the Taipei Basin (modified from Chen et al. 2007). White arrows: inactive faults; Red arrow: active fault. 
orogen growth was propagating southwestward along the passive continent margin of the Eurasian plate (Suppe 1984). The northern part of the mountain belt, including the Taipei metropolitan area, is now in a transtensional regime due to the westward propagation of the Ryukyu subduction system (Hu et al. 1996, 2002). The extension of the Taipei basin is possibly affected by the southward propagation of active collision (Teng et al. 2001; Chen et al. 2007).

The Taipei Basin is surrounded by the Tatung Volcano Group, Linkou Tableland and Western Foothills. The triangular-shaped half-graben Taipei Basin is filled with lateQuaternary fluvial deposits dating to about 0.4 Ma (Wei et al. 1998; Teng et al. 2001), which lie uncomformably over deformed Miocene sedimentary strata. The maximum thickness of deposits in the basin is about $700 \mathrm{~m}$ (Wang et al. 2004). The Tatun Volcano Group is mainly composed of late Quaternary andesitic volcanic formations. The Linkou Tableland located to the west of Taipei Basin is covered by Quaternary thick lateritic conglomerates as an ancient fan-delta which rests above Miocene/Pliocene sedimentary rocks (Chen and Teng 1990). The Western Foothhills are composed of fold-and-thrust belt of Miocene continental margin sedimentary strata.

One of the major natural hazards is potential flood inundation in the Taipei Basin induced by the rupture of the normal fault occurring along the Shanchiao fault. The lowlands created by fluvial process along the Tanshui River that passes through the Taipei Basin are densely populated and protected by levees along the banks with a 200-year return period protection level. The average elevation of the lowland areas in the Taipei Basin is about four meters above the mean sea level, and the elevation decreases mildly northward with a slope of approximately $0.1 \%$.

The Shanchiao fault separates the Taipei Basin and the Linkou Tableland (Fig. 1b), which is considered as the major active structure responsible for the ongoing extension (Chen et al. 2007). Huang et al. (2007) identified three paleoseismic events which occurred at 8400 - 8600, 9000 - 9300 and 11000 years B.P. Morphotectonic analysis showed a series of scarps between the tableland and the basin which mark the surface expression of the Shanchiao fault (Chen et al. 2010). These observations might imply that the Shanchiao fault is an active fault, thus a more complete assessment of the hazards is necessary for the Taipei Basin. We choose the areas bounded by river levees and elevation contour lines of $50 \mathrm{~m}$. Four zones of flood inundation simulation, including Beitou, Shilin, Lujhou and Sinjhuang, are shown in Fig. 2.

\subsection{Potential Earthquakes}

In order to evaluate the magnitude of an earthquake which would rupture the Shanchiao fault, it is necessary to understand the seismogenic regime in the study area. Al- though the seismicity is quite low in the Taipei metropolitan area, numerous earthquakes still occur in this area (Hsu 1983; Wang 1998; Lin 2005). One of the destructive earthquakes in the study area was an event in 1694 in the Emperor Kangshi period during the Ching Dynasty which had an estimated magnitude of 6.5 according to $\mathrm{Wu}$ (1978) and 7.0 by Hsu (1983). This event is assumed to have resulted in the formation of Kanshi Taipei Lake (Shyu et al. 2005). Based on the stratigraphic record from boreholes drilled along the Shanchiao fault, the maximum displacement for each subsidence ranged from 2.3 to $4.5 \mathrm{~m}$ (Huang et al. 2007). These observations are consistent with the estimates of Wang (2008) who suggested that a maximum displacement of $3.28 \mathrm{~m}$ could occur due to the rupture of Shanchiao and Chinshan fault by a magnitude 7.0 event.

One of the important parameters for estimating the magnitude of an earthquake that would rupture the Shanchiao fault is the dimensions of the fault (fault length and fault width). Based on the relationship between displacement and fault length, several authors have estimated the rupture length and magnitude of the event occurring along the Shanchiao-Chinshan fault system (e.g., Shyu et al. 2005; Huang et al. 2007; Chiu et al. 2008; Wang 2008). These studies have suggested that the length of the Sanchiao fault is about $11 \mathrm{~km}$, extending from south of the Tanshui River to Sinjhuang (Lin et al. 2000). The length of the northward extension of the Shanchiao fault to the Tatun volcano area is an important variable to consider. Shyu et al. (2005) suggested that a magnitude 6.9 event could rupture the ShanchiaoChinshan fault system with a total fault length of $45 \mathrm{~km}$ and a fault width of $15 \mathrm{~km}$. However, Wang (2008) argued

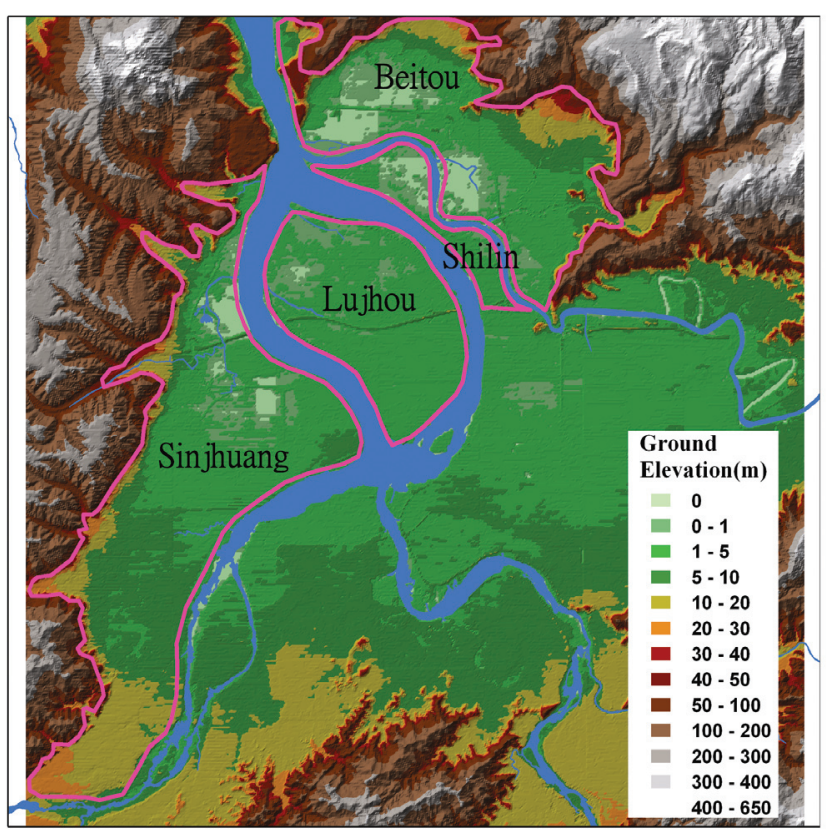

Fig. 2. Four inundation simulation zones. 
that Shyu et al. (2005) overestimated the fault width. Wang (2008) suggested an earthquake of magnitude 6.3 - 7.8 with a maximum slip of $0.27-39.35 \mathrm{~m}$, based on the empirical regression equation of Wells and Coppersmith (1994), and a fault length of $45 \mathrm{~km}$. Wang (2008) also proposed an optimum magnitude of 7.0 with a maximum slip of $3.28 \mathrm{~m}$. Huang et al. (2007) calculated an earthquake with magnitude ranging from 6.9 to 7.1 with a surface rupture length from 33 to $48 \mathrm{~km}$, based on the inferred displacement of 2.3 to $4.5 \mathrm{~m}$ along the Shanchiao fault.

Recently, shallow seismic reflection surveys have been conducted north of the Tanshui River and further north to the Chinshan area to delineate the northward extension of the Shanchaio fault (Shih et al. 2008). They found the total length of the Shanchiao fault was more than $36 \mathrm{~km}$. Based on LiDAR-derived DEM, Chan et al. (2005) observed the existence of a normal fault system in Tatun Volcano Group. Furthermore, inversion structures from reverse fault to normal fault were observed in the seismic profiles of CPC in the offshore area (Hsiao 1996). These observations can lead to valuable constraints regarding the potential earthquake magnitude and the fault geometry and dimensions. However, the coseismic topographic changes induced by the potential reactivation of the ShanchiaoChinshan fault system strongly depend on the slip patterns along the fault plane.

\subsection{Hydrological Data}

River stage heights are usually higher than those of storm sewer flow and overland flow in lowlands during periods of intense precipitation leading to flooding. It is not feasible to drain surface runoff by gravity with the high river stage; therefore, the openings (i.e., gates as crossing passes or outlets of the pumping stations) of the levees are closed during flooding. The flood propagation characteristics of surface runoff depend on the topography of the land surface. Therefore, flood inundation is strongly related to topography. Moreover, flood propagation is also impeded by obstructions existing on the land surface such as buildings, vegetation, other structures, etc. (Hsu et al. 2000). The impediment of flow by frictional resistance can be related to the Manning's roughness coefficient which is usually used to represent the friction term when describing water flow in channels (Wasantha Lal 1998; Hsu et al. 2002).

Typhoons and torrential rains have often affected Taiwan and brought about serious damage and loss of life. Among recent typhoons, Typhoon Nari was particular because of its unique track on 16 September 2001. Due to warm sea surface temperatures and the steep terrain of Taiwan, Nari brought heavy rainfall and flash flooding. Serious economic and societal damage, including 92 human lives lost, resulted (Sui et al. 2002). The cumulative rainfall for a 24 hour period was $669 \mathrm{~mm}$ during Typhoon Nari at the
Wudu rain gauge station located in northern Taiwan, which was the second highest 24 hour rainfall recorded in Taiwan (The 10th River Management Office 2002).

There are total 54 rain gauges recording rainfall data in the Taipei Basin. The spatial distribution of rainfall was estimated using the Kriging approach. Figure 3 shows the equal precipitation contours (isohyets) of Typhoon Nari at the rainfall intensity peak of the Sanchong station. Figure 4 shows the rainfall hyetograph at the Sanchong during Typhoon Nari, which will be employed as the input for inundation simulation to verify the $2 \mathrm{D}$ inundation model in next section.

In order to investigate the potential inundation hazards with different levels of disaster prevention in terms of different return periods, rainfall of various return-period events were analyzed. The hyetograph of the rainfall pattern in northern Taiwan as shown in Fig. 5 was generated using the alternating block method from an intensityduration-frequency (IDF) curve (Chow et al. 1988). Available rainfall records from 1897 to 2001 in the Taipei Basin were used in a frequency analysis adopting the log-Pearson Type III distribution. The frequency-based rainfall intensity of various durations is obtained to determine the IDF curve by Horner's equation (Chow et al. 1988). According to a report by the Water Resources Agency (2003), the total rainfall in a 200-year return-period event with 24-hr duration at Sanchong is $543 \mathrm{~mm}$ with a peak rainfall intensity of $75 \mathrm{~mm} \mathrm{hr}^{-1}$. Using the peak of rainfall intensity at the Sanchong as an example, the spatial total rainfall distribution for northern Taiwan for a 24-hr 200-year rainfall event is shown in Fig. 6. Other total rainfalls for various return-period events for 5-, 10-, 25-, 50-, and 100-year return periods and their corresponding peak values of rainfall intensity are listed in Table 1.

\section{METHODS}

\subsection{Dislocation Model}

We used the Poly3D software developed by the Stanford University (Thomas 1993) for forward modeling of surface deformation in the Taipei Basin (Huang et al. 2007) and the estimation of fault length of Shanchiao-Chinshan fault system. The advantage of the Poly3D code is that this method can evaluate the displacements, strains and stresses induced in an elastic whole- or half-space by planar, polygonal-shaped elements of a displacement discontinuity. In addition, the polygonal elements in Poly3D are well-suited for modeling complex surfaces with curved boundaries (Maerten et al. 2005). Fault surfaces which change in both strike and dip can be meshed by triangular elements without creating gaps or overlaps. Triangular elements are more flexible for simulating complex geometries than rectangular elements (Okada 1985). Division of surfaces into triangular elements allows for construction of three dimensional fault surfaces 
that more closely approximate listric surfaces and curved tiplines without introducing overlaps or gaps. We used this advantage of triangular elements to closely fit the surface fault trace and listric Shanshiao normal fault (Fig. 7).

The fault length is $55 \mathrm{~km}$ and fault width is $25 \mathrm{~km}$. The dip angle changes gradually from $80^{\circ}$ near the surface to $50^{\circ}$ at the depth of $9 \mathrm{~km}$, then to $50^{\circ}$ at deepest part.
We used the relationship between maximum displacement and fault length reviewed by Kim and Sanderson (2005) to understand how surface deformation varied over different length scales. Because the hypercenter of historical events are poorly constrained, the maximum slip of each event was assumed to be at a depth of $9 \mathrm{~km}$ below the bedrock of the Taipei Basin.

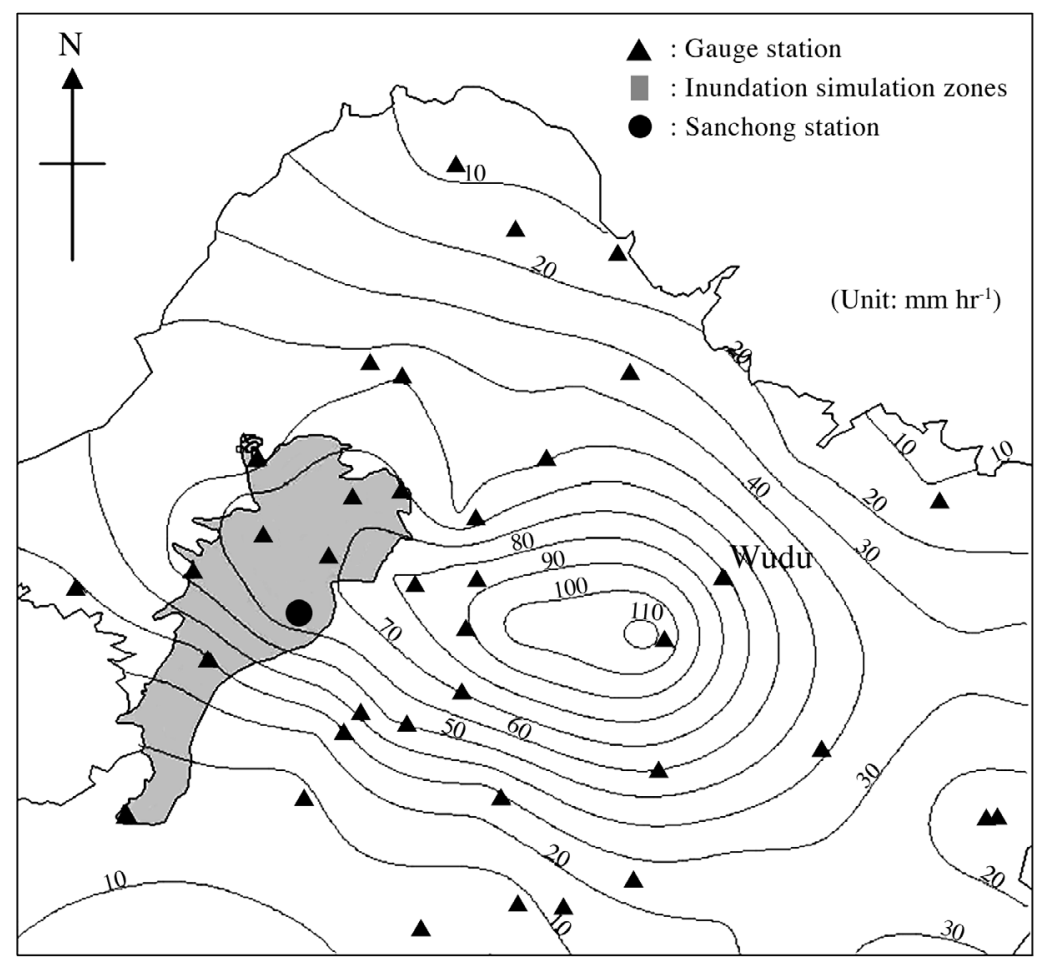

Fig. 3. Peak rainfall intensity distribution of Typhoon Nari in 2001.

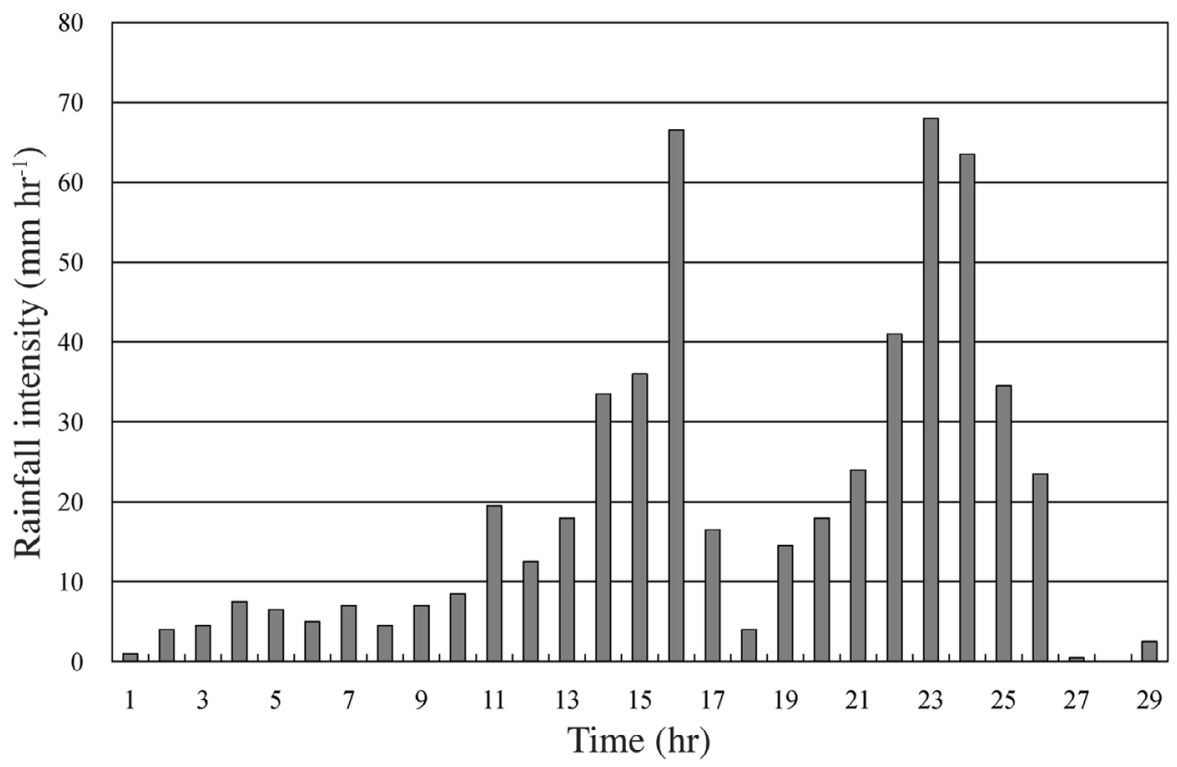

Fig. 4. Rainfall hyetograph of Typhoon Nari at the Sanchong station. 


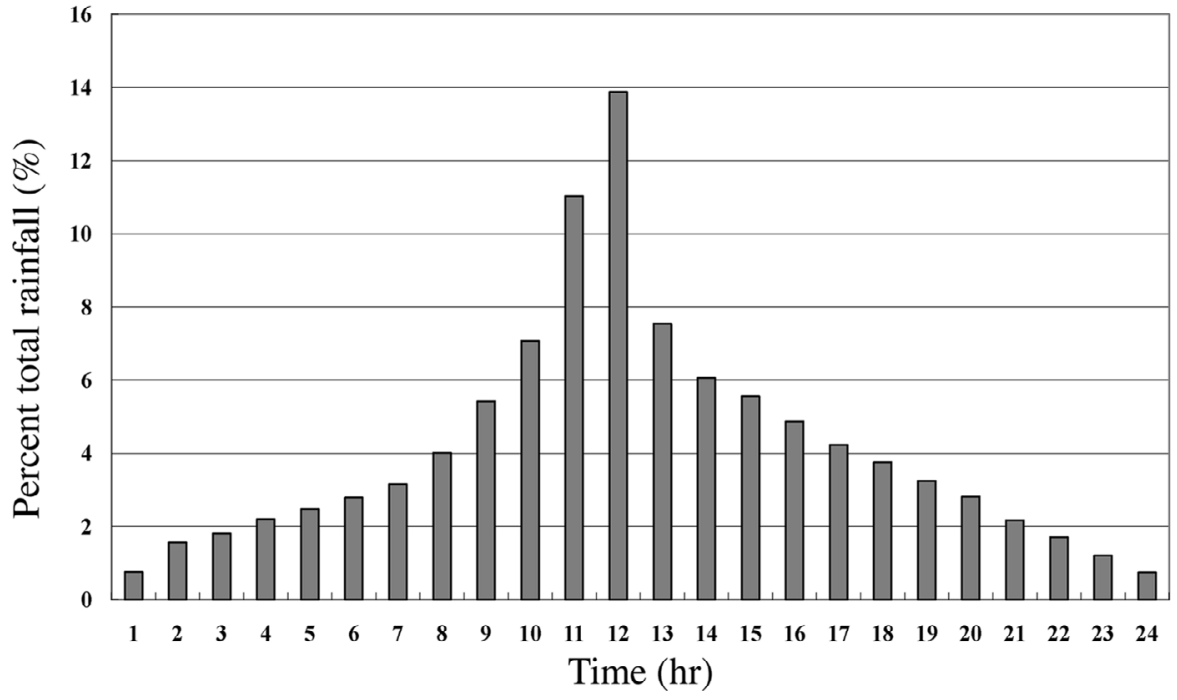

Fig. 5. Rainfall pattern for 24-hr duration in Northern Taiwan.

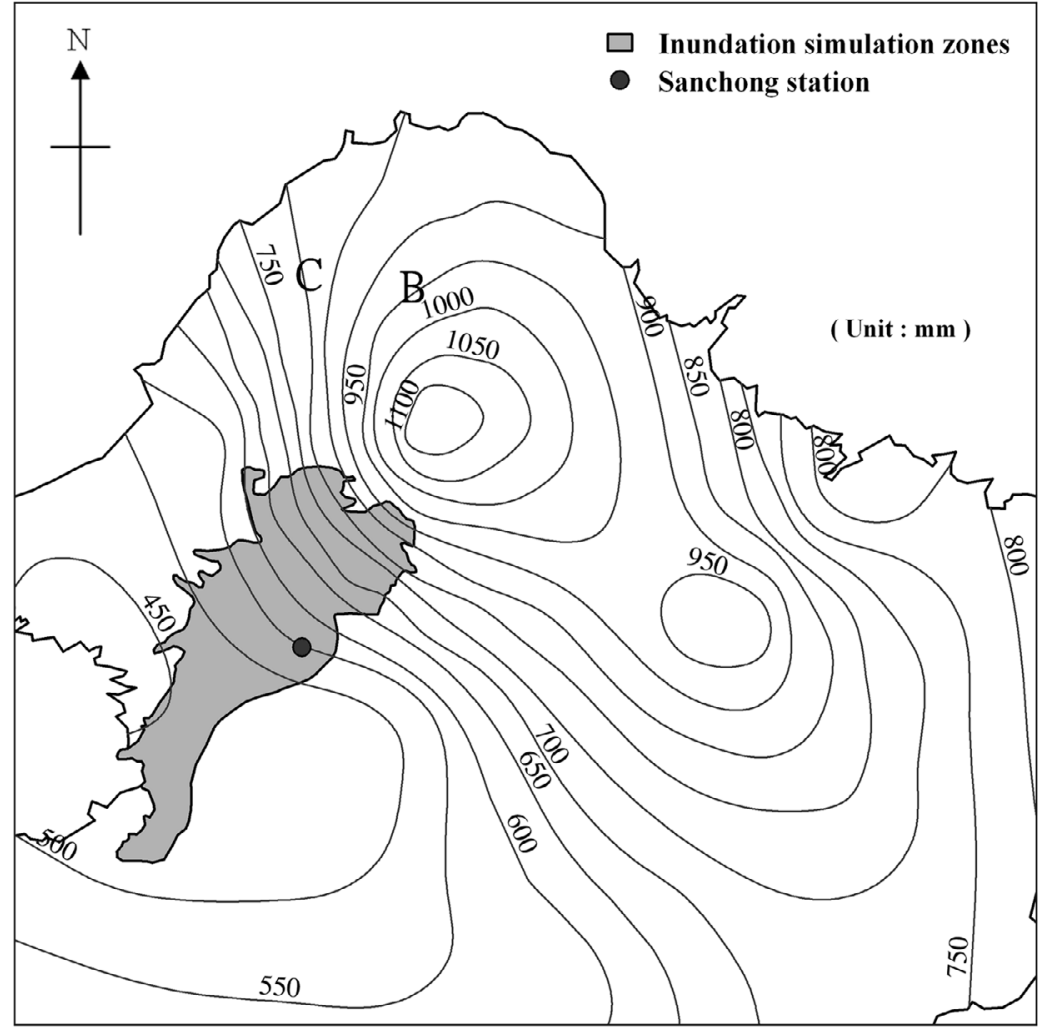

Fig. 6. Spatial total rainfall distribution in a 200-year 24-hr event.

Table 1. Total 24 hour rainfall and corresponding peak rainfall intensity for various return-period events at the Sanchong station.

\begin{tabular}{l|ccccc}
\hline Return period (year) & 5 & 10 & 25 & 50 & 100 \\
Total rainfall (mm) & 268 & 320 & 387 & 433 & 485 \\
Peak rainfall intensity $\left(\mathbf{m m ~ h r}^{-1}\right)$ & 37 & 44 & 54 & 60 & 673 \\
\hline
\end{tabular}




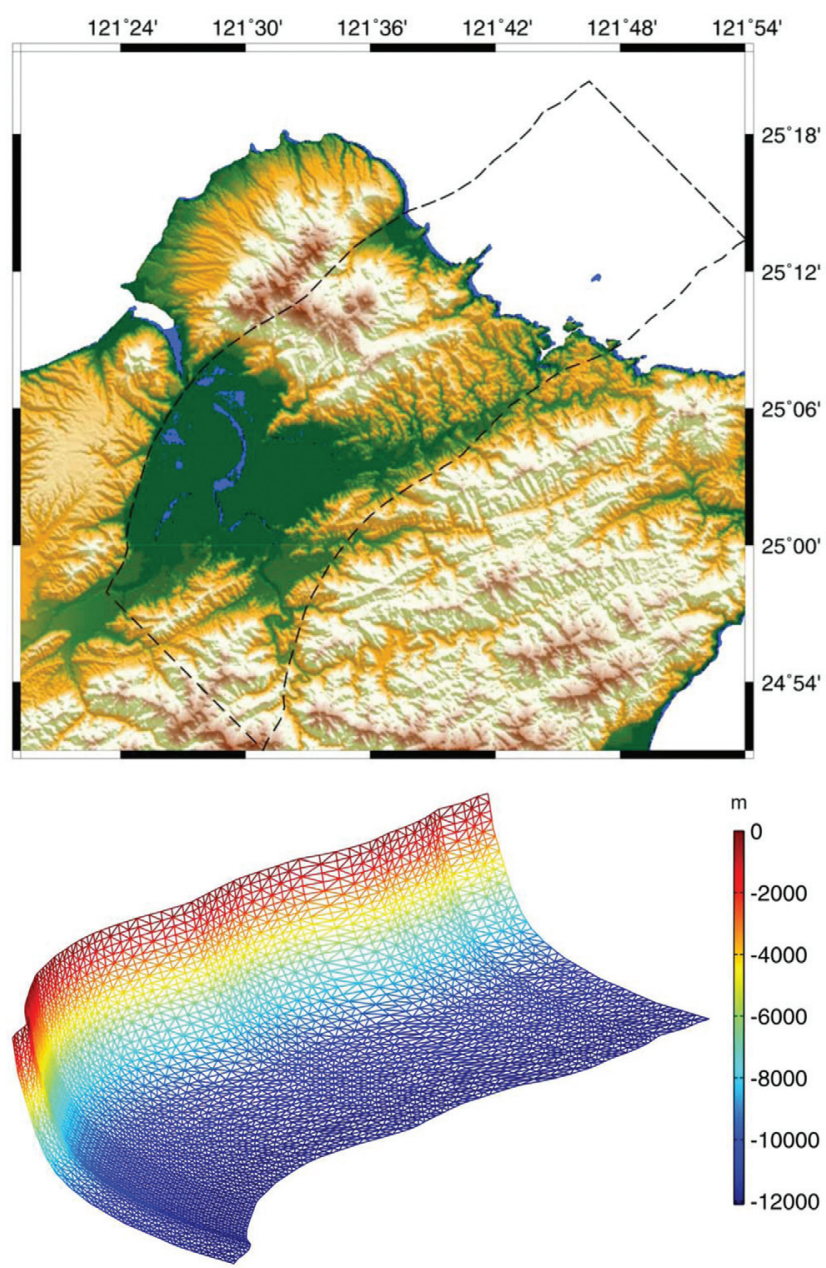

Fig. 7. The construction of three-dimensional fault plane of Shanchiao fault.

Displacements $D^{p}$ at points $(p)$ on the Earth's surface due to slip $S^{e}$ on elements $(e)$ of a buried fault can be described by a set of linear equations

$D^{p}=G^{e, p} S^{e}+E$

where $E$ are the observational errors and $G^{e, p}$ are the Green's functions that describe how slip on a fault element produces displacement at the Earth's surface. This set of equations can be used to forward model surface displacements from known fault geometry and slip distribution.

To carry out the inverse problem, we searched for a solution that simultaneously minimized the L-2 norm of the data misfit and of the model roughness. This method allows fitting of the data to a desired threshold while incorporating the geological concept that slip distributions are somewhat smooth rather than oscillatory (Segall and Harris 1986). As for minimizing the model roughness and misfit, this procedure can prevent overfitting of noisy data and compensate for underdetermined model parameters and geometrical in- accuracies. The misfit and model roughness of the slip inversion can thus be written as:

$\min \left[\|G s-D\|_{2}+\varepsilon^{-2}\|\Delta m\|_{2}\right]$

where $\|G s\|_{2}$ is the L-2 norm of the data misfit and $\varepsilon^{-2}\|\Delta m\|_{2}$ is a measure of the model roughness. The data misfit was calculated by subtracting the observed displacements, $d$, from the modeled displacements, which were themselves calculated by multiplying the Green's functions $G$ by the modeled slip $m$. The model roughness term is composed of a scalar smoothing parameter, $\varepsilon$, multiplied by the L-2 norm of a discrete second-order difference operator, $D$. This term includes Laplacian modeled slip, $\nabla^{2} m$, in order to minimize the non-dimensional model roughness which is defined as the change in fault slip per length of fault squared (Segall and Harris 1986).

The maximum slip was assumed to occur underneath the deepest Tertiary bedrock at the northwestern margin of Taipei Basin. Based on the empirical regression of fault length and magnitude, a maximum fault slip of $3.28 \mathrm{~m}$ was estimated for an earthquake of magnitude 7.0 (Wang 2008). However, based on the analysis of borehole data, Huang et al. (2007) suggested the inferred displacement of along the Shanchiao fault ranges from 2.3 to $4.5 \mathrm{~m}$ which could yield an earthquake magnitude of 6.9 and 7.1, respectively. Kim and Sanderson (2005) proposed a scaling law for the relationship between maximum cumulative displacement on a fault and the maximum linear dimension of the fault surface. Therefore we tried several different rupture centers at different depths. We found that when the depth of rupture center was less than $9 \mathrm{~km}$, it could result in the rupture length greater than $30 \mathrm{~km}$. For example, if the rupture center is located at depth of $7 \mathrm{~km}$, the predicted rupture length is $32 \mathrm{~km}$ and the maximum surface slip is about $2.5 \mathrm{~m}$. For the rupture depth at $5 \mathrm{~km}$, the predicted rupture length is about $35 \mathrm{~km}$ and the maximum surface slip is about $4.5 \mathrm{~km}$. These predicted surface slip lengths are consistent with the observation from borehole data which suggest a range of 2.3 to $4.5 \mathrm{~m}$ along the Shanchiao fault (Huang et al. 2007). Consequently, in our hazard assessment, the model with the rupture centre at the depth of about $5 \mathrm{~km}$ was selected (Fig. 8a). The area of subsidence due to coseismic displacement is about $450 \mathrm{~km}^{2}$ and the maximum subsidence is about $2.1 \mathrm{~m}$ (Fig. 8b).

\subsection{D Inundation Model}

\subsubsection{Basic Equations}

Assuming that acceleration term of water flow on the ground surface is small compared to gravitational and frictional terms, the inertial terms in the motion equations are neglected. The equation is for depth-averaged shallow water 
(a)

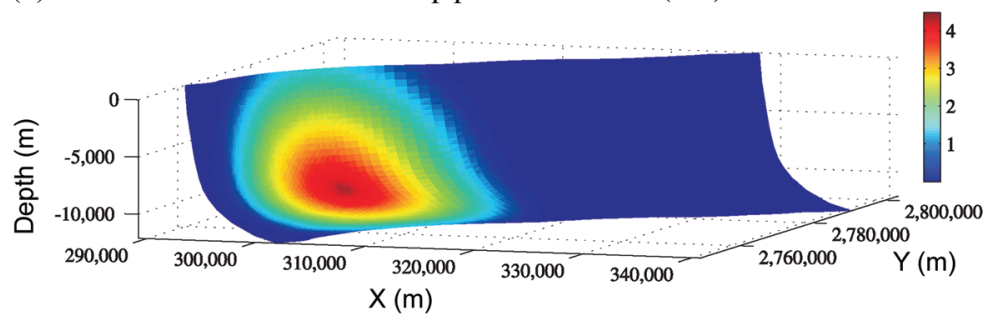

(b)

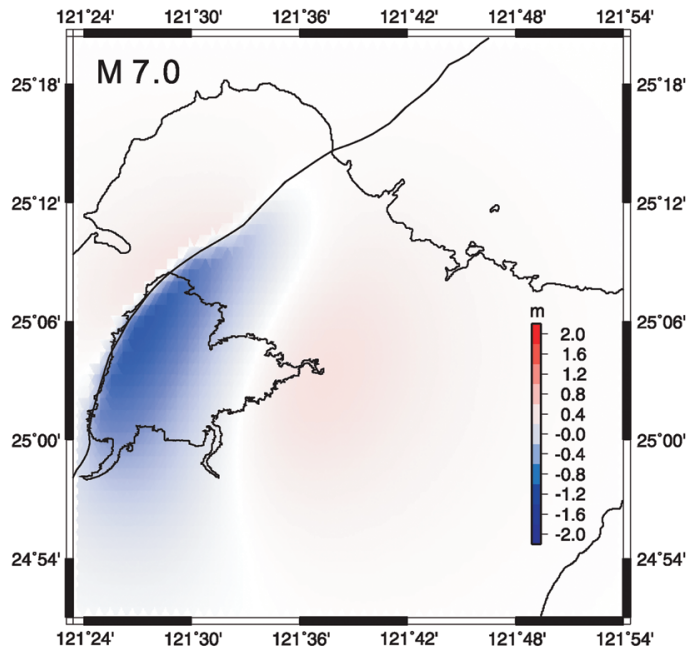

Fig. 8. (a) The slip along the fault plane with the maximum slip at the depth of $9 \mathrm{~km}$. (b) The coseismic vertical displacement field induced by a magnitude of 7.0 event on the fault of (a).

flow on the ground surface can be written as:

$\frac{\partial d}{\partial t}+\frac{\partial(u d)}{\partial x}+\frac{\partial(v d)}{\partial y}=q$

$-\frac{\partial(d+z)}{\partial x}=u\left[\frac{n^{2}|v|}{d^{4 / 3}}+\frac{q}{d \cdot g}\right]$

$-\frac{\partial(d+z)}{\partial y}=v\left[\frac{n^{2}|v|}{d^{4 / 3}}+\frac{q}{d \cdot g}\right]$

where $d$ is the depth of flow, $u$ is the velocity component in the $x$-direction, $v$ is the velocity component in the $y$-direction, $t$ is the time, $q$ is the source or sink per unit area, $z$ is the ground elevation, $n$ is Manning's roughness, and $g$ is the gravitational acceleration.

In this study, the two-step alternating direction explicit (ADE) scheme was adopted to establish the inundation model. The finite difference equations, derived from Eqs. (3) - (5) in each time step, are written as follows.

\section{At time step $(m+1 / 2)$}

$$
\begin{aligned}
d_{i, j}^{m+1 / 2}=d_{i, j}^{m}-\frac{1}{2} \Delta t & \left\{\frac{\left[\left(d^{m} u^{m+1 / 2}\right)_{i+1 / 2, j}-\left(d^{m} u^{m+1 / 2}\right)_{i-1 / 2, j}\right]}{\Delta x}\right. \\
& \left.+\frac{\left[(d v)_{i, j+1 / 2}^{m}-(d v)_{i, j-1 / 2}^{m}\right]}{\Delta y}-q_{i, j}^{m+1 / 2}\right\}
\end{aligned}
$$

$$
\frac{\left[(d+z)_{i, j}^{m+1 / 2}-(d+z)_{i+1, j}^{m+1 / 2}\right]}{\Delta x}=\left\{u^{m+1 / 2}\left[\frac{n^{2}|u|^{m+1 / 2}}{\left(d^{m}\right)^{4 / 3}}+\frac{q^{m+1 / 2}}{d^{m} g}\right]\right\}_{i+1 / 2, j}
$$

$$
\frac{\left[(d+z)_{i, j}^{m+1 / 2}-(d+z)_{i, j+1}^{m+1 / 2}\right]}{\Delta y}=\left\{v^{m+1 / 2}\left[\frac{n^{2}|v|^{m+1 / 2}}{\left(d^{m+1 / 2}\right)^{4 / 3}}+\frac{q^{m+1 / 2}}{d^{m+1 / 2} g}\right]\right\}_{i, j+1 / 2}
$$

where $m, i$ and $j$ are time, $x$ and $y$ are spatial indices, respectively, $\Delta t=t^{m+1}-t^{m}, \Delta x=x_{i+1}-x_{i}, \Delta y=y_{i+1}-y_{i}$. Using Eqs. (6) and (7), $u^{m+1 / 2}$ and $d^{m+1 / 2}$ in the $x$-direction can be solved simultaneously. Then $v^{m+1 / 2}$ can be obtained from Eq. (8).

\section{At time step $(m+1)$}

$$
\begin{aligned}
d_{i, j}^{m+1}= & d_{i, j}^{m+1 / 2}-\frac{1}{2} \Delta t\left\{\frac{\left[(d u)_{i+1 / 2, j}^{m+1 / 2}-(d u)_{i-1 / 2, j}^{m+1 / 2}\right]}{\Delta x}\right. \\
& \left.+\frac{\left[\left(d^{m+1 / 2} v^{m+1}\right)_{i, j+1 / 2}-\left(d^{m+1 / 2} v^{m+1}\right)_{i, j-1 / 2}\right]}{\Delta y}-q_{i, j}^{m+1}\right\}
\end{aligned}
$$

$\frac{\left[(d+z)_{i, j}^{m+1}-(d+z)_{i, j+1}^{m+1}\right]}{\Delta y}=\left\{v^{m+1}\left[\frac{n^{2}\left|v^{m+1}\right|}{\left(d^{m+1 / 2}\right)^{4 / 3}}+\frac{q^{m+1}}{d^{m+1 / 2} g}\right]\right\}_{i, j+1 / 2}$

$\frac{\left[(d+z)_{i, j}^{m+1}-(d+z)_{i, j+1}^{m+1}\right]}{\Delta x}=\left\{u^{m+1}\left[\frac{n^{2}\left|u^{m+1}\right|}{\left(d^{m+1}\right)^{4 / 3}}+\frac{q^{m+1}}{d^{m+1} g}\right]\right\}_{i+1 / 2, j}$

In the second time step, Eqs. (9) and (10) are used to solve $v^{m+1}$ and $d^{m+1}$ in the $y$-direction, and Eq. (11) is used to solve for $u^{m+1}$ directly.

\subsubsection{Boundary Conditions}

For the simulation, the levees and the ground elevation contour lines of $50 \mathrm{~m}$ were defined as closed bound- 
aries. The levees designed to protect 200-year flood were assumed to be high enough to prevent river water flowing over the top of the levee. Along the levee, the lateral inflow normal to the closed boundary is set to be zero. For the accumulated rainfall of various return-period events, the pumping stations work normally with full capacity are assumed and treated as numerical sinks in inundation simulations for potential hazards.

\subsubsection{Model Verification}

A comparison of simulated results and measured data should be made to verify our inundation model. Typhoon Nari, which brought about the worst damage in the northern Taiwan in the last decade, was chosen as the study case for model verification. Considering the major subsidence areas shown in Fig. 2, four simulation zones bounded by river levees and contour lines at $50 \mathrm{~m}$ elevation, including Beitou, Shilin, Lujhou and Sinjhuang, were used to construct the grid meshes using a $40 \mathrm{~m} \times 40 \mathrm{~m}$ grid size. Manning's roughness was adjusted and set at be the values of $0.07,0.06$ and 0.07 for commercial, residential and industrial areas, respectively. For hydrological data as presented in Figs. 3 and 4, the spatial rainfall distribution with the equal precipitation contours of Typhoon Nari was calculated for each computational time at one hour intervals. In each grid, the rainfall intensity data is imposed as the source parameter $q$.

There are no precise survey data of inundation areas and depths during flooding. After Typhoon Nari, the survey data of the inundation areas only in Lujhou and Sinjhuang simulation zones were produced (The 10th River Management Office 2002). The simulation results compared with the surveyed inundation areas are shown in Fig. 9. For model verification, the inspection of simulation results and surveyed data reveals that most inundation situations can be reasonably simulated by the model.

\section{RESULTS AND DISCUSSION}

\subsection{Surface Subsidence Due to the Activation of the Shanchiao Fault}

The degree of seismic-induced land subsidence is a crucial aspect for a hazard assessment using our inundation model. Recently, borehole data, seismic profile and LiDAR survey made it possible to estimate the range of magnitude of paleoseismicity, the maximum and average displacement for paleoevent of the Shanchiao-Chinshan fault system. Due to the poor constraint of the slip pattern along the Shanchiao fault, we use the maximum slip of at a rupture centre underneath west margin of Taipei Basin where the thickness of late-Quaternary deposits is about $700 \mathrm{~m}$. We used models with varying rupture center depths with the constraints of inferred slips of 2.3 to $4.5 \mathrm{~m}$ from borehole data (Huang et al. 2007). When seismic moment-magnitude reaches 6.5, the hanging wall of Shanchiao fault could subside over $1 \mathrm{~m}$. The maximum subsidence value is over $2.1 \mathrm{~m}$ and the area subsides below elevation $0 \mathrm{~m}$ is about $40 \mathrm{~km}^{2}$ when a moment-magnitude 7.0 earthquake occurs along the Shanchiao fault. The region, spreads around Beitou, Shilin, Lujhou and Sinjhuang could be submerged by flood.

\subsection{Scenarios for Potential Inundation Hazards}

Based on the topography changes resulting from coseismic deformation of a potential magnitude 7.0 event, several scenarios of inundation situations, including flood inundation below high tide and potential inundation under various return-period events, were simulated.

\subsubsection{Flood Inundation below High Tide}

The lowlands in the Taipei Basin are protected by levees. Ground deformation induced by the reactivation of Shanchiao fault may cause cracking of concrete walls or embankments, resulting in levee failure. We assumed that there are sufficient openings on the broken levees due to uneven ground deformation. According to the periodic tides at the Tanshui River mouth, the tide ranges about from -1 to $+1 \mathrm{~m}$ under normal conditions. Not considering storms or typhoon rainfall, the water confined in the river may flow into the lowlands. At high tide (elevation $+1 \mathrm{~m}$ ), without pumping stations operating, the resulting inundation areas were estimated to cover about $33 \mathrm{~km}^{2}$, shown in Fig. 10, which covers about $15 \%$ of the Taipei metropolitan region. Four locations, namely Gandau (A), National Open University (B), Wugu (C) and Changping elementary school (D), were selected to show the flood inundation and propagation characteristics. As shown in Fig. 10, inundation depths at A - D were $1.77,2.83,1.86$, and $2.67 \mathrm{~m}$, respectively.

\subsubsection{Potential Inundation Simulations under Various Return-Period Events}

Regarding disaster prevention, six scenarios for potential inundation hazards were investigated using various return-period events for flood protection. Using the design rainfall pattern in Fig. 5 and total rainfall shown in Table 1, the potential inundation hazards before and after land subsidence for various return-period events were simulated.

A 200-year, 24-hr design rainfall was first simulated to analyze surface inundation without land subsidence induced by ground deformation. In the simulation zones bounded by levees, the pumping stations (see Fig. 10) were assumed to operate normally with full capacity during the flood events. Figure 11 shows the simulated inundation areas, recording the maximum inundation depth for each grid in computation. In general, the flooding areas occur in the lowlands with relatively low ground surface elevations, typically 


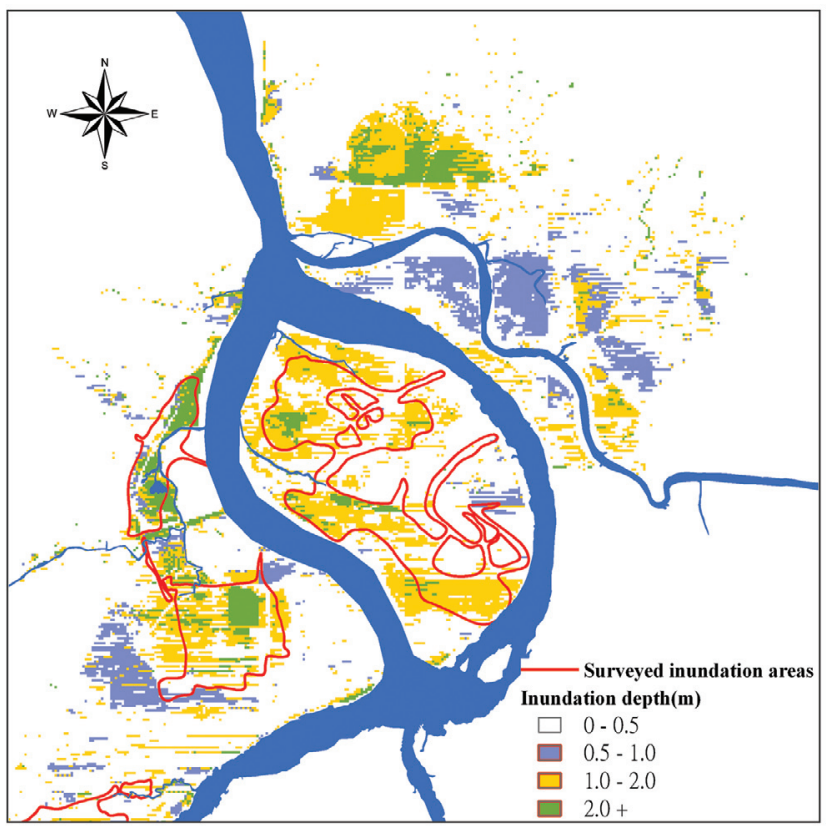

Fig. 9. Simulated and surveyed inundation areas in Typhoon Nari.

along the drainage systems or riverside regions. The hydrological inputs were the same as those in the case without ground deformation are given for the inundation simulation after land subsidence. The simulated results after subsidence are shown in Fig. 12. It is obvious that the higher inundation depths can be found after land subsidence, typically around the locations A - D (see Fig. 10). At locations near the Shanchiao fault, greater subsidence can occur. In addition, simulated inundation areas and depths depend on flood propagation characteristics which are affected by ground deformation. Other return periods for 5-, 10-, 25-, 50-, and 100-year rainfall events are also simulated. The results of simulated inundation areas and average depths are listed in Table 2 for comparison.

As listed in Table 2, the simulated inundation areas after land subsidence increase as the return periods of design rainfall increase, except for the 5-year return-period flood. This discrepancy may be attributable to surface runoff as overland flow which is trapped locally in the surface-deformed lowlands generates more serious inundation than that in the 5-year return-period flood. For a 200-year, 24-hr design rainfall condition, $8.8 \%$ increment of the inundation area after land subsidence can create significant difficulty in emergency response and rescue operation. Moreover, the average inundation depths listed in Table 2 were calculated by summing the water volume of each grid in the entire simulation zones and dividing by the simulated inundation area for corresponding design rainfall event. There is no regular tendency of depth increment while the total amount of design rainfall increases, which may be attributed to irregularity of ground surface.

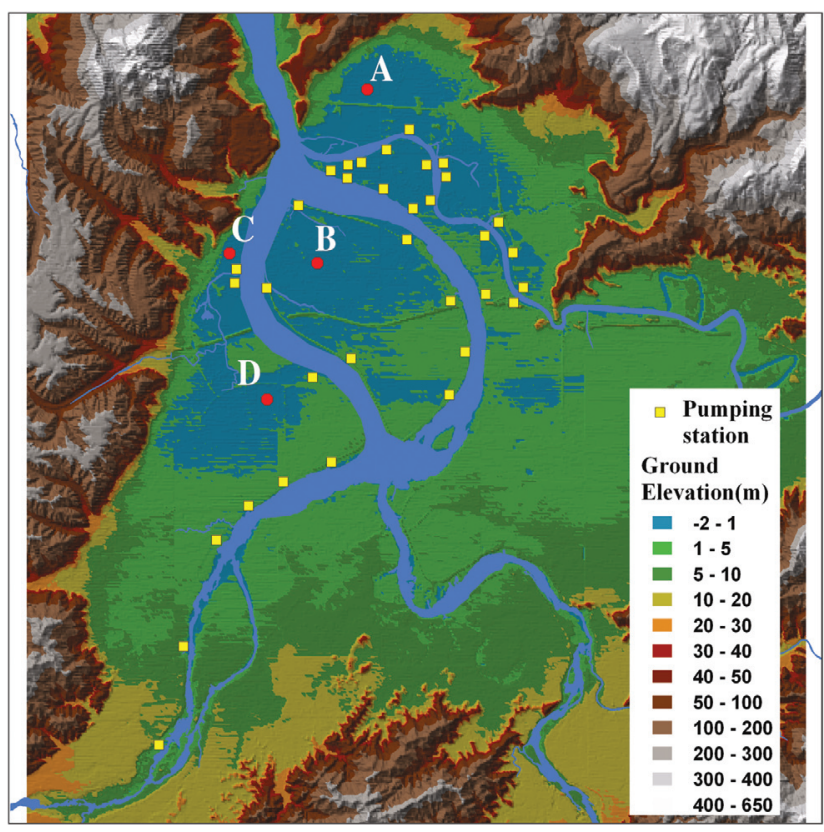

Fig. 10. Estimated inundation areas under high tide condition.

Nevertheless, the detailed water depth variations over time during inundation provide information on surface runoff propagation, which can be useful to schedule evacuation routes and transportation for local people in the flood event. Figure 13 shows the water depth variations at the observation points under a simulated 200-year 24-hr rainfall. As seen in Fig. 13, the water depth at Gandau (A) begins to rise about 10 hours after it rains. Twenty-four hours later, the water depth reaches $1.9 \mathrm{~m}$ deep without land subsidence, but the water depth can increase to $2.35 \mathrm{~m}$ deep after subsidence. In this case, surface runoff may flow toward the lowland in that area, and the water level rises gradually. The water depth variations at National Open University (B) showed a similar pattern to those at A. This indicates that surface runoff flows into that location raises the water depth after 10 hours and increases slowly until 16 hours; after that the water depth increases at a faster rate up to $0.5 \mathrm{~m}$ deep after 24 hours. For the observation point at Wugu (C), the water depth reaches the maximum depth at nearly the same level for both with and without subsidence. This shows that surface runoff propagates and gets trapped locally at that relatively low location. Although the ground elevation drops $1.86 \mathrm{~m}$ at $\mathrm{C}$, the inundation depth does not increase much by resulting land deformation. Basically, the ground elevation changes may alter the surface runoff direction of flood propagation to raise the water depth earlier than that without subsidence. Moreover, the water depths at $\mathrm{C}$ drop gradually after the peak inundation to demonstrate the effect of pumping station nearby. Likewise, the observation point at the Changping elementary school (D) presents a similar depth variation pattern as C. However, the pumping effect 
is more significant at this location and causes a decrease in depth. If the maximum inundation depth is sorted during each return-period flood, the maximum values of inundation depth can be plotted for various return-period events at each location as shown in Fig. 14. Except for D, it is apparent that the maximum inundation depth increases as the total amount of rainfall increases, and the depth difference with and without subsidence also increases when the rainfall return period increases.

\section{CONCLUSION}

Based on the empirical relationship between fault length

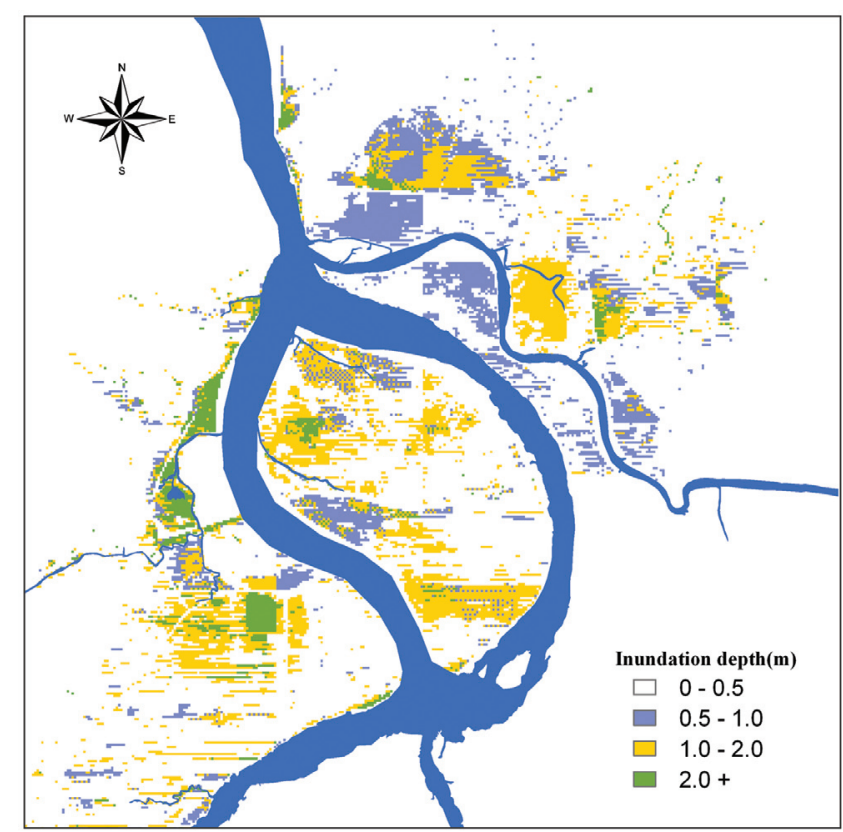

Fig. 11. Simulated inundation areas in a 200-year 24-hr flood. and magnitude, we used a half-space dislocation model to simulate the topographic changes induced by the magnitude of 6.5 - 7.0 earthquake occurring along the Shanchiao fault. When a magnitude of 6.5 event with a maximum slip along the Shanchaio fault rupture at a depth of $5-7 \mathrm{~km}$ underneath the west margin of the Taipei Basin near the Kuandu area, it can result in a coseismic subsidence area of about $340 \mathrm{~km}^{2}$ with maximum coseismic subsidence of $1.2 \mathrm{~m}$. When an earthquake of magnitude 7.0 ruptures, the coseismic subsidence area is about $450 \mathrm{~km}^{2}$ and the maximum coseismic subsidence is about $2.1 \mathrm{~m}$.

The 2D inundation model was first verified by comparing the simulated inundation areas with the measured

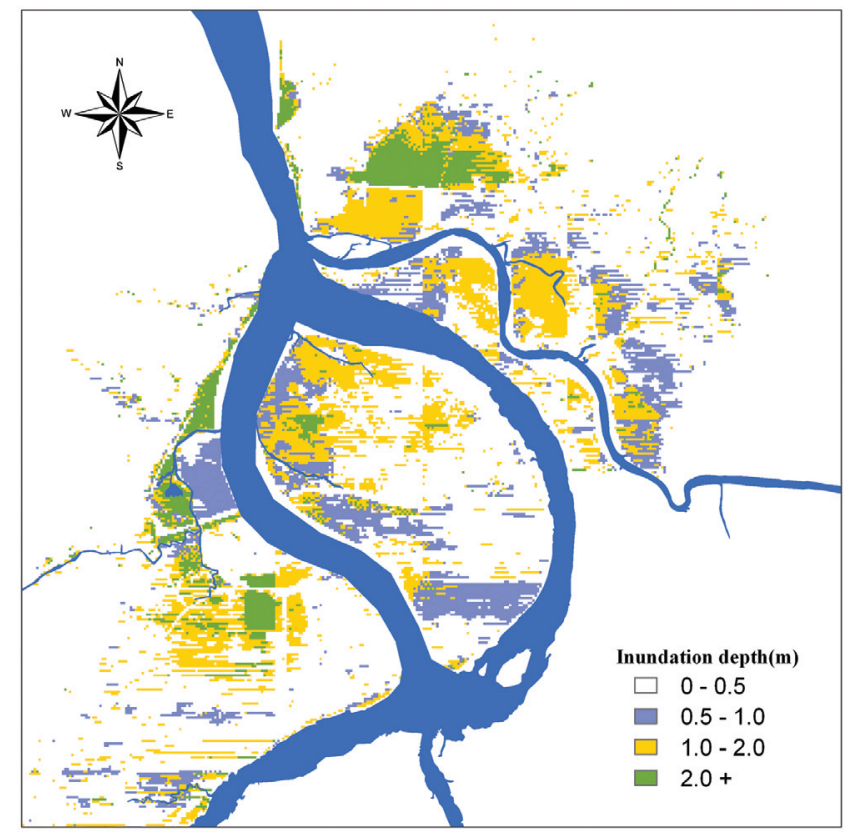

Fig. 12. Simulated inundation areas in a 200-year 24-hr flood after subsidence.

Table 2. Potential inundation areas and depths for various return-period events.

\begin{tabular}{|c|c|c|c|c|c|c|}
\hline \multirow{2}{*}{$\begin{array}{l}\text { Return } \\
\text { period } \\
\text { (year) }\end{array}$} & \multicolumn{3}{|c|}{ Inundation area $\left(\mathbf{k m}^{2}\right)$} & \multicolumn{3}{|c|}{ Average inundation depth (m) } \\
\hline & $\begin{array}{l}\text { Before land } \\
\text { subsidence }\end{array}$ & $\begin{array}{c}\text { After land } \\
\text { subsidence }\end{array}$ & $\begin{array}{c}\text { Increment } \\
(\%)\end{array}$ & $\begin{array}{l}\text { Before land } \\
\text { subsidence }\end{array}$ & $\begin{array}{c}\text { After land } \\
\text { subsidence }\end{array}$ & $\begin{array}{c}\text { Increment } \\
(\%)\end{array}$ \\
\hline 5 & 20.82 & 22.30 & 7.12 & 1.08 & 1.11 & 2.78 \\
\hline 10 & 24.16 & 24.50 & 1.39 & 1.14 & 1.21 & 6.14 \\
\hline 25 & 26.04 & 26.49 & 1.71 & 1.23 & 1.31 & 6.50 \\
\hline 50 & 26.68 & 28.49 & 6.76 & 1.29 & 1.34 & 3.88 \\
\hline 100 & 27.51 & 29.54 & 7.38 & 1.36 & 1.39 & 2.21 \\
\hline 200 & 28.60 & 31.12 & 8.79 & 1.41 & 1.43 & 1.42 \\
\hline
\end{tabular}




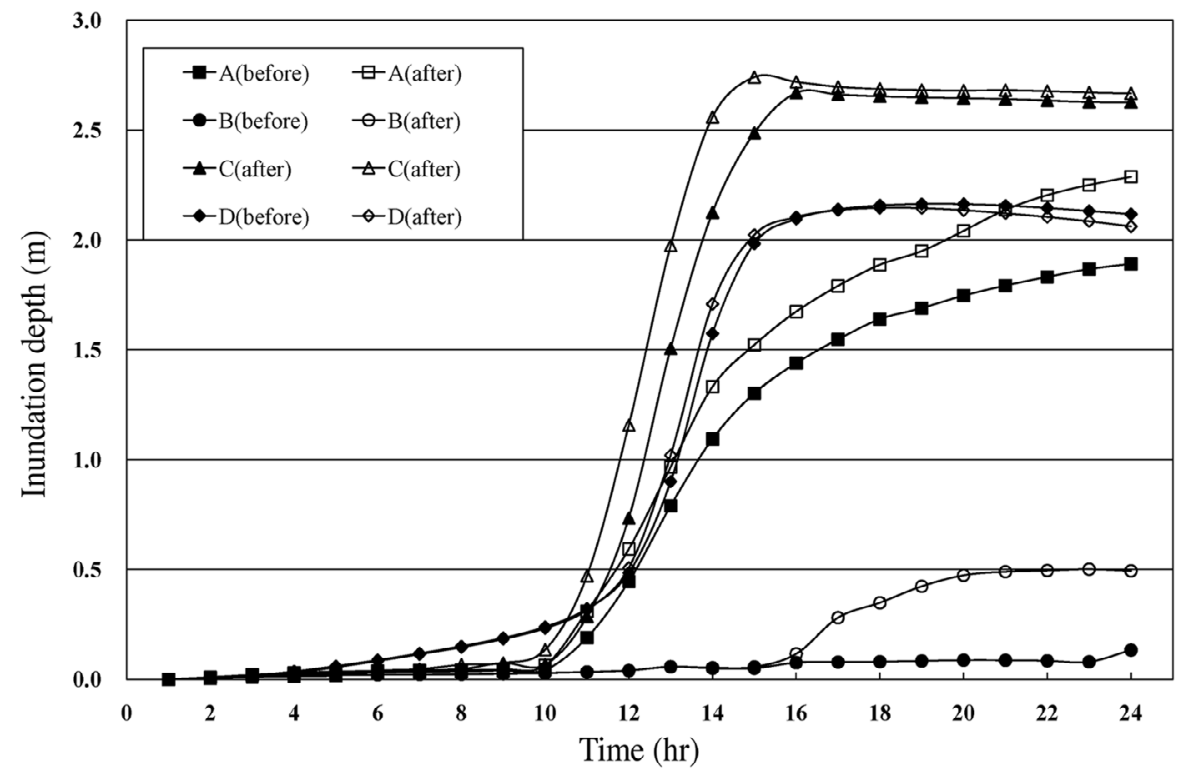

Fig. 13. Inundation hydrographs at the observation points in a 200-year 24-hr event.

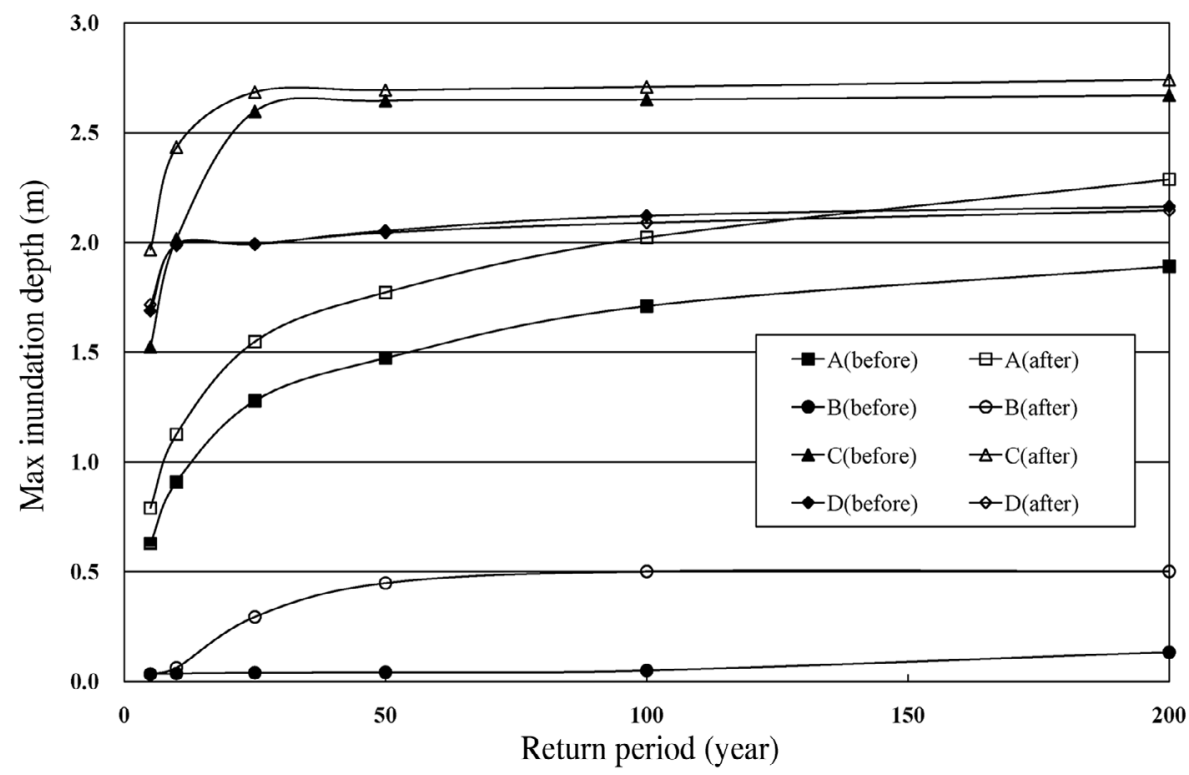

Fig. 14. Maximum inundation depths at the observation points in various return-period events.

data for Typhoon Nari event to show the applicability of the model. Based on the topography changes resulting from coseismic deformation in a potential magnitude 7 event, the 2D inundation model was adopted to simulate several scenarios of inundation situations due to land subsidence, including potential flood inundation below high tide condition and under various return-period design rainfall events.

Under high tide condition without the operation of pumping stations, the resulting inundation areas are estimated to have $33 \mathrm{~km}^{2}$ due to levee failure, which may cover about $15 \%$ the Taipei metropolitan region. The simulated inundation results show the larger inundation depths can be found after land subsidence, especially near the Shanchiao fault. Essentially, the simulated inundation areas and depths depend on flood propagation characteristics which are obviously affected by coseismic deformation. The simulated water depth variations during inundation provide information of surface runoff propagation with time, which might be useful to schedule evacuation routes and transportation plans for persons in the affected area. The resulting inundation maps based on various return-period events can also provide information for disaster emergency responses and 
flood mitigation measures such as infrastructure planning, with respect to potential hazards induced by reactivation of the Shanchiao fault.

Acknowledgements The comments and suggestions from two reviewers are deeply appreciated. This research was supported by the Taiwan Earthquake Research Center (TEC) funded through National Science Council (NSC) with grant number 97-2625-M-002-008. The TEC contribution number for this article is 00064 .

\section{REFERENCES}

Bates, P. D., K. J. Marks, and M. S. Horritt, 2003: Optimal use of high-resolution topographic data in flood inundation models. Hydrol. Process., 17, 537-557, doi: 10.1002/hyp.1113. [Link]

Cervelli, P., M. H. Murray, P. Segall, Y. Aoki, and T. Kato, 2001: Estimating source parameters from deformation data, with an application to the March 1997 earthquake swarm off the Izu Peninsula, Japan. J. Geophys. Res., 106, 11217-11237.

Chan, Y. C., J. C. Lee, R. F. Chen, K. C. Chang, J. K. Liu, W. C. Hsu, J. C. Hu, W. S. Chen, C. C. Yang, Y. G. Chen, D. Y. Cheng, S. Tsao, and Y. C. Hsieh, 2005: Airborne LIDAR mapping of the metropolitan Taipei area: Current status and progress. Proc. Symp. on Volcanic Activity and the Sanchiao Fault, Central Geol. Surv., MOEA, Taipei, Taiwan, ROC, 87-101. (in Chinese)

Chen, C. T., J. C. Hu, C. Y. Lu, J. C. Lee, and Y. C. Chang, 2007: Thirty-year land elevation change from subsidence to uplift following the termination of groundwater pumping and its geological implications in the Metropolitan Taipei Basin, Northern Taiwan. Eng. Geol., 95, 30-47, doi: 10.1016/j.enggeo.2007.09. 001. [Link]

Chen, C. T., J. C. Lee, Y. C. Chan, and C. Y. Lu, 2010: Growth normal faulting at the western edge of the Metropolitan Taipei Basin since the last glacial maximum, northern Taiwan. Terr. Atmos. Ocean. Sci., 21, 409428, doi: 10.3319/TAO.2009.11.13.01(TH). [Link]

Chen, W. F. and L. S. Teng, 1990: Depositional environment of Quaternary deposits of the Linkou Tableland, northwestern Taiwan. Proc. Geol. Soc. China, 33, 3963.

Chiu, C. Y., J. C. Hu, C. Y. Chen, H. C. Liu, 2008: Reactivation of the Shanchiao fault and its implication to variation of landforms in Taipei Basin. Spec. Publ., Cent. Geol. Surv., 20, 97-110.

Chow, V. T., D. R. Maidment, and L. W. Mays, 1988: Applied Hydrology. McGraw-Hill, New York.

Cunge, J. A., F. M. Holly, and A. Verwey, 1976: Practical Aspects of Computational River Hydraulics. Pitman
Advanced Pub. Program, London, 420 pp.

Dawers, N. H., M. H. Anders, and C. H. Scholz, 1993: Growth of normal faults: Displacement length scaling. Geology, 21, 1107-1110, doi: 10.1130/0091-7613(199 3)021<1107:GONFDL $>2.3 . C O ; 2$. [Link]

Ho, C. S., 1986: A synthesis of the geologic evolution of Taiwan. Tectonophysics, 125, 1-16, doi: 10.1016/00401951(86)90004-1. [Link]

Hsiao, L. Y. 1996: Late Cenozoic structures off northeastern Taiwan. Master Thesis, National Taiwan University, Taipei, Taiwan, ROC, 62 pp.

Hsu, M. H., J. S. Lai, and C. L. Yen, 1990: Two-dimensional inundation model for Taipei City. Proceedings of Fifth International Conference on Urban Storm Drainage, Osaka, Japan, 169-174.

Hsu, M. H., S. H. Chen, and T. J. Chang, 2000: Inundation simulation for urban drainage basin with storm sewer system. J. Hydrol., 234, 21-37, doi: 10.1016/S0022-16 94(00)00237-7. [Link]

Hsu, M. H., S. H. Chen, and T. J. Chang, 2002: Dynamic inundation simulation of storm water interaction between sewer system and overland flows. J. Chin. Inst. Eng., 25, 171-177.

Hsu, M. T., 1983: Estimation of earthquake magnitude and seismic intensities of destructive earthquakes in the Ming and Ching Eras. Meteorol. Bull. CWB, 29, 1-18. (in Chinese)

Hu, J. C., J. Angelier, J. C. Lee, H. T. Chu, and D. Byrne, 1996: Kinematics of convergence, deformation and stress distribution in the Taiwan collision area: 2-D finite-element numerical modelling. Tectonophysics, 255, 243-268, doi: 10.1016/0040-1951(95)00140-9. [Link]

Hu, J. C., S. B. Yu, J. Angelier, and H. T. Chu, 2001: Active deformation of Taiwan from GPS measurements and numerical simulations. J. Geophys. Res., 106, 22652280, doi: 10.1029/2000JB900196. [Link]

Hu, J. C., S. B. Yu, H. T. Chu, and J. Angelier, 2002: Transition tectonics of northern Taiwan induced by convergence and trench retreat. Geol. Soc. Am., Special Paper, 358, 147-160, doi: 10.1130/0-8137-2358-2.147. [Link]

Huang, S. Y., C. M. Rubin, Y. G. Chen, and H. C. Liu, 2007: Prehistoric earthquakes along the Shanchiao fault, Taipei Basin, northern Taiwan. J. Asian Earth Sci., 31, 265-276, doi: 10.1016/j.jseaes.2006.07.025. [Link]

Kim, Y. S. and D. J. Sanderson, 2005: The relationship between displacement and length of faults: A review. Earth-Sci. Rev., 68, 317-334, doi: 10.1016/j.earscirev. 2004.06.003. [Link]

Lin, C. H., 2005: Seismicity increase after the construction of the world's tallest building: An active blind fault beneath the Taipei 101. Geophys. Res. Lett., 32, L22313, doi: 10.1029/2005GL024223. [Link] 
Lin, C. W., H. C. Chang, S. T. Lu, T. S. Shin, and W. J. Huang, 2000: An Introduction to the Active Faults of Taiwan, $2^{\text {nd }}$ Ed., Explanatory Text of the Active Fault Map of Taiwan. Spec. Publ. Cent. Geol. Surv., 13, 122 pp. (in Chinese)

Lin, K. C., J. C. Hu, K. E. Ching, J. Angelier, R. J. Rau, S. B. Yu, C. H. Tsai, T. C. Shin, and M. H. Huang, 2010: GPS crustal deformation, strain rate, and seismic activity after the 1999 Chi-Chi earthquake in Taiwan. $J$. Geophys. Res., doi: 10.1029/2009JB006417, in press.

Maerten, F., P. Resor, D. Pollard, and L. Maerten, 2005: Inverting for slip on three-dimensional fault surfaces using angular dislocations. Bull. Seismol. Soc. Am., 95, 1654-1665, doi: 10.1785/0120030181. [Link]

Okada, Y., 1985: Surface deformation due to shear and tensile faults in a half-space. Bull. Seismol. Soc. Am., 75, 1135-1154.

Segall, P. and R. Harris, 1986: Slip deficit on the San Andreas fault at Parkfield, California, as revealed by inversion of geodetic data. Science, 233, 1409-1413, doi: 10.1126/science.233.4771.1409. [Link]

Shih, R. C., C. W. Lin, H. C. Liu, and S. T. Lu, 2008: Northward extension of the Sanchiao fault in northern Taiwan from the shallow seismic reflection images. West. Pac. Earth Sci., 6, 149-168.

Shyu, J. B. H., K. Sieh, Y. G. Chen, and C. S. Liu, 2005: Neotectonic architecture of Taiwan and its implications for future large earthquakes. J. Geophys. Res., 110, B08402, doi: 10.1029/2004JB003251. [Link]

Sui, C. H., C. Y. Huang, Y. B. Tsai, C. S. Chen, P. L. Lin, S. L. Shieh, M. H. Li, Y. A. Liou, T. C. C. Wang, R. S. Wu, G. R. Liu, and Y. H. Chu, 2002: Meteorologyhydrology study targets Typhoon Nari and Taipei flood. Eos, Trans., AGU, 83, 265, doi: 10.1029/2002 EO000186. [Link]

Suppe, J., 1984: Kinematics of arc-continent collision, flipping of subduction and back-arc spreading near Taiwan. Mem. Geol. Soc. China, 6, 21-33.

Teng, L. S., 1990: Geotectonic evolution of late Cenozoic arc-continent collision in Taiwan. Tectonophysics, 183, 57-76, doi: 10.1016/0040-1951(90)90188-E. [Link]

Teng, L. S., 1996: Extensional collapse of the northern Taiwan mountain belt. Geology, 24, 949-952, doi: 10.11 30/0091-7613(1996)024<0949:ECOTNT>2.3.CO;2. [Link]

Teng, L. S., C. T. Lee, C. H. Peng, W. F. Chan, and C. J. Chu, 2001: Origin and geological evolution of the Taipei Basin, northern Taiwan. West. Pac. Earth Sci., 1,
115-142.

The 10th River Management Office, 2002: Investigation of the flooding of Tanshui river in typhoon Nari. Water Resources Agency, Taiwan.

Thomas, A. L., 1993: Poly3D: A three-dimensional, polygonal element, displacement discontinuity boundary element computer program with application to fractures, faults and cavities in the Earth's crust. Master Thesis, Stanford University, Stanford, CA, 97 pp.

Vongvisessomjao, S., T. Tingsanchali, and C. Chaiwat, 1985: Bankok flood plain model. 21st IAHR Congress, Melbourne, Australia, 19-23 August, 433-438.

Wang, C. Y., Y. H. Lee, M. L. Ger, and Y. L. Chen, 2004. Investigating subsurface structures and $\mathrm{P}$ - and $\mathrm{S}$-wave velocities in the Taipei Basin. Terr. Atmos. Ocean. Sci., 15, 609-627.

Wang, J. H., 1998: Studies of earthquake seismology in Taiwan during the 1897-1996 period. J. Geol. Soc. China, 41, 291-336.

Wang, J. H., 2008: Potential earthquakes rupturing the Chinshan and Shangjiao faults in the Taipei Metropolitan Area. Terr. Atmos. Ocean. Sci., 19, 205-212, doi: 10.3319/TAO.2008.19.3.205(T). [Link]

Wang, J. H., M. W. Huang, and W. G. Huang, 2006: Aspects of $M \geq 4$ earthquakes in the Taipei Metropolitan area during 1973-2005. West. Pac. Earth Sci., 6, 169-190.

Wasantha Lal, A. M., 1998: Performance comparison of overland flow algorithms. J. Hydr. Engrg., ASCE, 124, 342-349, doi: 10.1061/(ASCE)0733-9429(1998) 124:4(342). [Link]

Water Resources Agency, 2003: Hydrological planning and design in correspondence to environmental change. Report of the Water Resources Agency, Ministry of Economic Affairs, Taipei, Taiwan, ROC.

Wei, K., Y. G. Chen, and T. K. Liu, 1998: Sedimentary history of the Taipei Basin with constraints from thermoluminescence dates. J. Geol. Soc. China, 41, 109125 .

Wells, D. L. and K. J. Coppersmith, 1994: New empirical relationships among magnitude, rupture length, rupture width, rupture area, and surface displacement. Bull. Seismol. Soc. Am., 84, 974-1002.

Wu, F. T., 1978: Recent tectonics of Taiwan. J. Phys. Earth, 2 (Suppl.), S265-S299.

Yu, D. and S. N. Lane, 2006: Urban fluvial flood modelling using a two-dimensional diffusion-wave treatment, part 1: Mesh resolution effects. Hydrol. Process., 20, 1541-1565, doi: 10.1002/hyp.5935. [Link] 